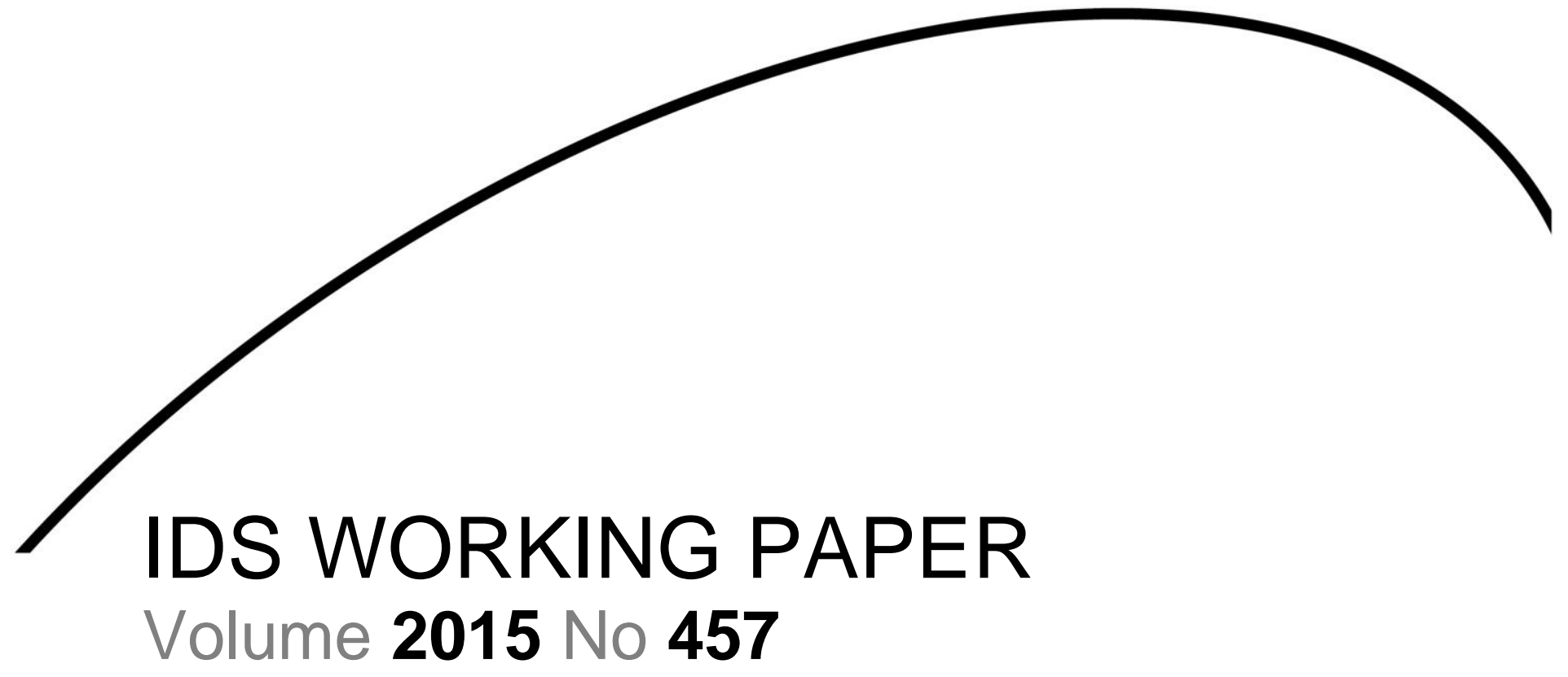

\title{
Inequality, Social Cooperation and Local Collective Action
}

Patricia Justino

June 2015 
Inequality, Social Cooperation and Local Collective Action

Patricia Justino

First published by the Institute of Development Studies in June 2015

IDS Working Paper 457

(C) Institute of Development Studies 2015

ISSN: 2040-0209 ISBN: 978-1-78118-238-3

A catalogue record for this publication is available from the British Library.

All rights reserved. Reproduction, copy, transmission, or translation of any part of this publication may be made only under the following conditions:

- with the prior permission of the publisher; or

- with a licence from the Copyright Licensing Agency Ltd., 90 Tottenham Court Road, London, W1P 9HE, UK,

or from another national licensing agency; or

- under the terms set out below.

This publication is copyright, but may be reproduced by any method without fee for teaching or nonprofit purposes, but not for resale. Formal permission is required for all such uses, but normally will be granted immediately. For copying in any other circumstances, or for re-use in other publications, or for translation or adaptation, prior written permission must be obtained from the publisher and a fee may be payable.

\section{Available from:}

Communications and Engagement Unit, Institute of Development Studies, Brighton BN1 9RE, UK

Tel: +44 (0) 1273915637

E-mail: bookshop@ids.ac.uk

Web: www.ids.ac.uk/publications

IDS is a charitable company limited by guarantee and registered in England (No. 877338) 


\title{
Inequality, Social Cooperation and Local Collective Action
}

\author{
Patricia Justino
}

\section{Summary}

This paper examines the relationship between inequality and collective action, and identifies a range of mechanisms that shape the association between income inequality and local collective action. These include (i) individual motivations to participate in collective action groups, (ii) group-level cooperation and trust, and (iii) the efficiency and coordination of collective organisations. The paper proposes in addition an agenda for future research on the links between inequality, social cooperation and collective action.

Keywords: inequality; cooperation; collective action; mechanisms.

Patricia Justino is a Professorial Fellow at the Institute of Development Studies at the University of Sussex, UK. She is a development economist specialising in applied microeconomics. Her current research work focuses on the impact of violence and conflict on household welfare and local institutional structures, the implications of violence for economic development and the role of inequality on institutions and conflict. She has led several research projects funded by the British Academy, DFID, the European Commission, the ESRC, FAO, the Leverhulme Trust, UNDP, UNESCO, UN Women and the World Bank. She was the Director of MICROCON (www.microconflict.eu) and is co-founder and co-director of the Households in Conflict Network (www.hicn.org). Since June 2010, Patricia has led the Conflict and Violence cluster at IDS. 


\section{Contents}

Summary 3

Acknowledgements 5

$\begin{array}{lr}\text { Introduction } & 6\end{array}$

$1 \quad$ Why does inequality matter for development? $\quad 7$

2 Inequality, social cooperation and collective action 9

2.1 Inequality and motivations for individual participation in collective action
groups

2.2 Inequality and group-level cooperation and trust 10

2.3 Efficiency and coordination of collective organisations in the presence of
inequalities

$3 \quad$ Final remarks: a new research agenda? 13

$\begin{array}{ll}\text { References } & 15\end{array}$ 


\section{Acknowledgements}

The author would like to thank Ana Maria Ibáñez and John Gaventa for useful comments and discussions. Funding for the production of this working paper has been provided through the IDS-DDLGN core contribution 2012-2014. The views expressed in this paper are the author's alone. 


\section{Introduction}

Economic development is typically accompanied by a certain level of inequality: different people have different abilities and different initial endowments of physical, human and social capital. However, inequalities are also shaped by a variety of structural factors and social, economic and political disparities ranging from the uneven distribution of opportunities, resources and power across society, to colonial legacies and other historical and institutional processes. These inequalities are often associated with the exclusion of some population groups from the benefits of development, and may pose constraints on the establishment of fully functioning market economies and democratic political systems. There is mounting evidence that vulnerable groups have been largely excluded from the benefits of economic growth in many countries in the world. High rates of urbanisation have, in addition, resulted in the proliferation of slums and large areas where state presence is minimal. Recent global developments including the Arab Spring events, food riots and the Occupy movement have highlighted the rise of these forms of inequality across the world, while academic research has shown evidence for dramatic increases in the incomes and wealth shares of those at the top of the distribution (Piketty 2013), and in overall material disparities between the 'haves' and 'have-nots' (Milanovic 2011).

There is a large literature across the social sciences on the causes and consequences of different forms of inequality. The general consensus is that equality matters not only for its impacts on economic development but also as a normative good (Sen 1973; Rawls 1971). A large body of literature has shown that high levels of persistent inequality affect negatively the functioning of markets, the accumulation of human capital and sociopolitical stability. Equality and social justice are also goals shared across most societies. This paper discusses one critical effect of inequality that has remained largely under-researched: on forms of collective action, i.e. on how people come together (or not) to achieve common societal goals.

Much has also been written about the role of collective action and civil society organisations in addressing social, economic and political inequalities throughout history (e.g. Paige 1975; Scott 1976). A large literature has examined the impact of collective action on addressing inequalities through demands for redistributive policies (e.g. Boix 2003). Justino (2006, 2007, 2015) shows how government transfers have been associated with reductions in civil unrest in India motivated by social discontent and demands for redistribution. Labour unions, in particular, have played active roles in the reduction of inequalities through their influence on local job practices undertaken by public and private enterprises, and lobbying for the interests of otherwise disadvantaged groups in the design of national policies (see Freeman and Medoff 1984). Other important collective action organisations include user committees in the management of common resources, local credit groups, village committees for the management and provision of public goods, self-help groups and agricultural cooperatives.

Bringing about more equal opportunities and outcomes requires organised action: in order to work, collective organisations need to rely on the participation of and cooperation between different segments of society, to benefit from efficient communication channels, and to be able to voice actively the demands of those they represent. This is not straightforward. In particular, inequalities within heterogeneous groups and asymmetries in bargaining power may limit social cooperation and interactions and, thus, the functioning and effectiveness of collective action (Baland and Platteau 2006; Banerjee, Mookherjee, Munshi and Ray 2001; Bardhan 2005). This is a particularly important challenge in developing countries where local forms of collective action have been heralded as a way of breaking development barriers (World Bank 2000, 2004), particularly in areas where state institutions are weak or inefficient (Ostrom 1990). 
The relationship between inequality and collective action has received increasing attention in the development literature, notably in research concerned with the management of common property resources (see Baland, Bardhan and Bowles 2006). But collective action is also important for a variety of other development outcomes beyond common resources, including access to credit, insurance and the exercise of citizenship rights. This paper attempts to shed some light on the relationship between inequality and local collective action by making use of emerging literature on these complex relationships. The paper focuses on mapping out and discussing the mechanisms that may shape the association between income inequality and local collective action. The paper is organised as follows. Section 2 provides a brief review of the importance of income inequality for development. Section 3 discusses three key mechanisms that underlie a potential relationship between inequality and collective action: individual motivations to participate in collective action groups, group-level cooperation and trust, and the efficiency and coordination of collective organisations. Section 4 concludes the paper by outlining an agenda for future research on the links between inequality, social cooperation and collective action.

\section{Why does inequality matter for development?}

The analysis of inequality has recently taken on a central role in the development debate due to the increase in income inequality observed in a significant number of industrialised and developing countries (Atkinson and Piketty 2007, 2010; Milanovic 2002, 2011; Oxfam 2014; Piketty 2013). An extensive literature has shown that a large number of individuals and households remain poor and excluded from the benefits of economic development due to the persistence of high levels of economic, social and political inequality. They remain poor not necessarily because they live in poor countries - in fact much poverty and social exclusion persists in high-income economies - but because high levels of inequality create exclusion and pockets of persistent poverty among certain population groups (Bowles, Durlauf and Hoff 2006; World Bank 2003b).

High levels of income inequality are typically correlated with forms of social, economic and political exclusion, and with both the structure and the level of poverty in any given society (Ravallion 2005 2013). Its impact can be direct, when it affects how households and individuals access economic (markets, employment), social (education, health) and political (voting, political organisations) institutions. Or it can have an indirect impact by affecting the type and rate of economic growth in a given economy and, consequently, the income and consumption levels of different population groups. The ineffectiveness of economic growth in reducing poverty in high-inequality countries has been well documented (Birdsall and Londoño 1997; Ravallion 1997). A body of influential literature has also provided ample evidence of the harmful effects of inequality on economic growth via several channels.

One important channel is the implementation of efficient macroeconomic management policies. In general, the higher the initial level of inequality, the higher the negative impact of price fluctuations and other monetary variables (for instance, interest rates) on economic development, and the more limited will be the scope for the implementation of nondistortionary monetary and fiscal policies (Gottschalk 2003). On the one hand, the higher the inequality of incomes and assets, the higher the number of economically vulnerable individuals and thus the higher the degree of volatility the economy will be exposed to (Gottschalk 2003). On the other hand, high inequalities restrain the demand capacity of poor and middle-income countries (Murphy, Shleifer and Vishny 1989). Reductions in income inequality lead to a wealthier middle class (enlarged by those coming out of the poorer classes), which are the most significant consumers of manufactured goods. Consequently, the reduction of inequalities is likely to induce an increase in private consumption and, 
consequently, an enlargement of internal markets and higher prospects for economic growth. High levels of inequality may also impede the establishment of pro-poor trade policies and emphasise possible negative distributional impacts caused by international economic shocks (McCulloch, Winters and Cirera 2001; Winters 2002; Wood 1994).

This body of literature has not only emphasised the market-distortive effects of inequality but has also shown how persistently high levels of income inequality may affect economic efficiency through losses in individual productivity. Notably, high income inequality may result in reductions in the stock of human capital available in each economy when it leads to the persistence of illiteracy and poor health among disadvantaged groups. Dilapidated stocks of human capital will, in turn, decrease individuals' capacity to access better jobs and higher incomes. This will, in turn, reflect in the countries' inability to pursue higher rates of economic growth (Galor and Zeira 1993; Perotti 1993; Ribero and Nuñez 1999; Saint-Paul and Verdier 1992).

Several other studies have shown that persistently high levels of inequality not only affect the economy and individual productivity but can also have profoundly negative effects on societies through effects on discontent and social cohesion. Most of this literature has focused on the effects of inequality on social outcomes related to stability, notably crime and other forms of social and political conflict. The reasoning behind these results is that the persistence of inequalities among certain socioeconomic groups may increase social discontent and, consequently, the propensity of individuals and/or groups to engaging in criminal activities, violence and even wars. Inequality has been associated with an increased risk of crime (Becker 1967; Fajnzylber, Lederman and Loayza 1998; Sala-i-Martin 1996), and forms of sociopolitical conflict (Gupta 1990; Lichbach 1989). Several studies have also shown a close association between armed conflict and income and asset inequality (Muller and Seligson 1987; Schock 1996), class divides (Paige 1975; Scott 1976), horizontal inequality between ethnic, religious and other cultural groups (Langer 2004; Murshed and Gates 2005; Østby 2006; Stewart 2000, 2002), relative deprivation (Gurr 1970), levels of polarisation (Esteban and Ray 1994; Esteban and Schneider 2008; Montalvo and ReynalQuerol 2008) and ethnic fragmentation (Easterly and Levine 1997).

What is less understood is why and when inequalities will result in the breakdown of social cohesion to high enough levels that result in violence. While social exclusion and inequality persist in many countries across the world, only a handful of these countries have experienced or will experience violence and conflict. This is because the 'primary causal sequence in political violence is first the development of discontent, second the politicization of the discontent, and finally its actualization in violent action against political objects and actors' (Gurr 1970: 13). I have argued elsewhere that two factors may explain the relationship between inequality and the 'actualisation' of discontent into violence (Justino 2013). The first is the nature and structure of inequalities within each society, which will determine the point at which inequality will be seen as a sufficiently serious infringement of the social contract between states and citizens or between citizens themselves. The second is the type of structures in place at the level of the state and markets - and also, fundamentally, at the level of the civil society - that may either reduce the propensity or create the space and opportunity for certain actors to resort to violence and conflict as a strategy to manage social, economic and political differences. This begs the question: How does inequality shape social cooperation and collective action across societies? 


\section{Inequality, social cooperation and collective action}

A recent body of research has argued that the emergence of inclusive and democratic societies is largely explained by how institutions manage social diversity and different interests at historical transition points (Acemoglu and Robinson 2006; Boix 2003; Engerman and Sokoloff 2002; North, Wallis and Weingast 2009). North et al. (2009) refer to the importance of 'open access' societies, where citizens are treated in similar ways, limiting the emergence of exclusion, grievances and their translation into violent outcomes. Acemoglu and Robinson (2012) discuss the role of 'inclusive institutions' in promoting virtuous cycles of innovation, economic growth and peace. Besley and Persson (2011) refer to the significance of 'common interests' and the management of differences in the transition towards more inclusive development processes. A common thread across this literature is that violence will emerge when inequalities result in 'extractive' institutional processes that promote exclusion and further dysfunctional inequalities.

Inequalities affect not only how state institutions function, but also how local self-governing institutions deliver local public goods. Notably, high levels of inequality may lead to local institutional failures when resources and power are captured by elites at the expense of poorer and more vulnerable sections of the population (Bardhan 2005; Ostrom 1990; Platteau 2004). These effects are of particular concern in developing countries where local governing institutions (formal or informal) are central to the organisation of societies when governments are unable to provide adequate public goods, and insurance, credit and other markets are absent (Fafchamps 1992; Ostrom 1990; Rosenzweig 1988; Townsend 1994). Collective action is also an important determinant of poverty and development processes in these contexts (Akerlof 1976; Coleman 1990; Durlauf 2006; Easterly, Ritzen and Woolcock 2006; North 1990; Ostrom 1990; Putnam 1993; Woolcock 1998). The success of local collective action is, in turn, dependent on the bonds of social cooperation within and across communities (Barrett 2005; Habyarimana, Humphreys, Posner and Weinstein 2009).

Inequalities are likely to affect profoundly the social fabric of local communities and their ability to cooperate. Inequalities may affect social relations between family members, neighbours and acquaintances, how communities relate internally and with other communities, and the functioning of local citizen organisations and their relation with statelevel institutions. I explore below three mechanisms whereby inequalities may affect collective action, through their impact on: (i) individual motivations to participate in collective action groups; (ii) group-level cooperation and trust; and (iii) the efficiency and coordination of collective organisations.

\subsection{Inequality and motivations for individual participation in collective action groups}

Income inequality may affect individual decisions to participate in collective organisations. First, standard median-voter models predict that when inequality in a certain society is high the median voter is located closer to the vast majority of poor voters. In those circumstances, policies targeted at the median voter should be pro-poor (Meltzer and Richard 1981). However, this result is highly dependent on the political influence of those at the top of the distribution, and the net effect of inequality on political and civil participation will be shaped by the interests of the elites (Piketty 1996). The reality observed in most high-inequality countries is that the provision of public goods tends to systematically exclude the poor (World Bank 2003a). Moreover, the link between inequality and political participation often creates barriers - when the poor cannot afford to vote or are bought out by richer votes - that prevent the poor from voicing their demands in equal weight to the rich and participating in 
equal terms in forms of collective organisation (Lijphart 1997). Tilly's (1998) work was one of the first theoretical efforts to systematically analyse the persistence of inequalities caused by differences between societal categories. 'Durable' inequalities between different social or political categories arise 'because people who control access to value-producing resources solve pressing organizational problems by means of categorical distinctions. Inadvertently or otherwise, those people set up systems of social closure, exclusion, and control' (Tilly 1998: 8). The persistence of political inequalities among disadvantaged groups implies, in turn, the exclusion of large fractions of the population from the development process, resulting in lower levels of redistribution (Piketty 1996), and creating barriers to the trickle-down of the potential benefits of economic growth to the whole population (Datt and Ravallion 1992). However, in some circumstances, elites may have a sufficiently high interest in promoting civic participation. This may be the case when exclusion may threaten the status quo of elites (Acemoglu and Robinson 2006; Boix 2003), or when societies have a relatively high tolerance for inequality due to high expectations that they will do better in the future - a phenomenon Hirschman (1981) famously described as the 'tunnel effect'. The net effect of inequality of participation in this case is a priori unclear, and depends on perceptions of inequality and interactions between elite and citizen interests.

Second, inequalities may also affect individual aspirations and expectations. It is possible that some levels of inequality may result in higher aspirations and expectations, notably in societies where the 'tunnel effect' operates. In this case, individual engagement in collective action may be seen as a way of climbing the ladder and achieving aspirations for higher individual welfare. Recent studies have, however, shown a link between high inequalities and low aspirations (Genicot and Ray 2014; Ray 2006). This effect may be shaped by the persistence of self-fulfilling beliefs (Bourdieu 1986) or identity-based preferences (Akerlof and Kranton 2000), which result in individuals at the bottom of the distribution internalising their inability to climb the ladder and, as a result, assuming behaviours that keep them at the bottom. Aspirations and expectations are, in particular, shaped by family and immediate social circumstances, which tend to transmit values, wealth, tastes and beliefs through peereffects and across generations (Bowles et al. 2006). One channel is wealth inheritances, which, in the presence of imperfect credit markets, result in dynasties with little initial wealth facing limited investment opportunities and remaining poor (Piketty 2000, 2013). Other channels include the transmission of productive abilities and efficient human capital investments across generations (Piketty 2000), the family transmission of ambition and other tastes conducive to high productive ability (Piketty 2000), and positive assortative matching whereby individuals of a certain social status and levels of skills tend to relate to (and marry) similar individuals (Kremer 1993). These effects may lower aspirations and expectations among those at the bottom of the distribution, resulting in less engagement in forms of collective action, such as voting (Lijphart 1997, 1999), or other forms of collective organisation (Cardenas 2006).

\subsection{Inequality and group-level cooperation and trust}

Social cooperation - the bonds that shape social relations and bring people together - is one of the most fundamental pillars of social order, responsible for how political systems, markets and social structures are organised, including how collective action and forms of collective organisation emerge (Akerlof 1976; Ostrom 1990). Social cooperation does not necessarily need to result in forms of collective action and organisation. But effective collective action in general requires a certain level of social cooperation. The development economics literature has provided wide-ranging evidence for the importance of norms of group-level cooperation and trust on several social, economic and political outcomes. Individual and household group membership (for instance, of race, religion and ethnic groups, local associations and so forth) has been shown to affect significantly human and social capital outcomes (Durlauf 1996; Fafchamps and Lund 2002), including the persistence of inequalities due to 'neighbourhood' effects (Durlauf 1996; Wilson 1995) and social segregation (Bowles, Loury and Sethi 2014). The norms, preferences and beliefs that shape social cooperation and trust have also been 
shown to be central to how people relate to each other, how collective action emerges and how citizens engage with state and non-state organisations (Algan and Cahuc 2010;

Attanasio, Barr, Cardenas, Genicot and Meghir 2012; Bernard, Dercon and Taffesse 2011; Jappelli and Pistaferri 2000; Knack and Keefer 1997; Ray 2006). Social cooperation is also viewed as key to political and social stability (Varshney 2002; World Bank 2011). Group-level trust and cooperation are therefore likely to be central mechanisms to understanding how inequality affects collective action.

There is now a substantial literature on the formation of group cooperation (Axelrod and Hamilton 1981; Bowles and Gintis 2011; Gambetta 1988) and trust (Glaeser, Laibson, Scheinkman and Soutter 2000; Karlan, Möbius, Rosenblat and Szeidl 2009). While few studies to date have offered a systematic analysis of which causal mechanisms might explain why inequalities (and what inequalities) may sometimes break group cooperation and trust, recent literature has suggested that high levels of inequality may affect social preferences around trust, altruism and reciprocity (Attanasio et al. 2012; Bowles and Gintis 2011; Cox 2004; Gambetta 1988; Thöni, Tyran and Wengström 2012), preferences for egalitarianism (Alesina and Rodrik 1994; Alesina, Cozzi and Mantovan 2012) and individual beliefs grounded on people's expectations (about the behaviour of others and about future outcomes) (Manski 2004; Ray 2006; Schelling 1966). These behavioural channels are in turn likely to vary across gender, age, ethnicity, religion, caste and class (Alesina and LaFerrara 2005; Banerjee, lyer and Somanathan 2005; Besley, Coate and Loury 1993; Eckel and Grossman 2001; Habyarimana et al. 2009), either leading to more inclusive local organisations or to further entrenching existing structural inequalities (Bowles et al. 2014. The net effect is a priori ambiguous and likely to depend on the levels of inequality observed within groups and between groups.

While some levels of heterogeneity between groups may facilitate collective action, particularly when elites may benefit from the collective good (Olson 1965), high levels of heterogeneity within groups (across ethnic and wealth levels) have been shown to reduce group cooperation at the local level (Alesina and LaFerrara 2005; Bardhan 2005; Miguel and Gugerty 2005). For instance, Alesina and LaFerrara (2002) have shown that that interpersonal trust is lower in communities with higher income inequality in the USA. Nunn and Wantchekon (2011) have traced the origins of the relationship between group inequalities and trust in Africa to the slave trade, which appears to still shape current associations between high inequality and low levels of trust at the community level. This literature suggests that more homogeneous groups are more likely to exhibit stronger levels of cooperation and trust.

However, internally homogeneous groups may also be characterised by forms of 'parochialism' (Bowles and Gintis 2004, 2011) when inequalities between groups are significant, leading to suspicion and discrimination against 'other' groups. In these cases, it is possible that high levels of inequality across different groups or communities will enhance collective action within those groups that will further increase the gap between different groups in the population. Anti-migrant attitudes or violence against non-native groups are examples of this phenomenon - what was described elsewhere as the 'dark side of social capital' (see Schelling 1966). Phenomena such as this may result in reductions in inter-group cooperation as different social groups drift apart (Akerlof and Kranton 2000; Hoffman, McCabe and Smith 1996; Kranton 1996). This point was made in Piketty (2013), who discussed how the increasing disconnection between the top 1 per cent and the rest of the population in several developed countries might result in further wealth accumulation at the top, and the exclusion of most of the population from the benefits of economic growth.

Another example of inequalities between groups leading to reductions in between-group cooperation and trust is that of local segregation into unequal communities. Benabou (1993), for instance, has shown that the provision of public goods and education opportunities are 
greater in richer neighbourhoods than in the poorer neighbourhoods due to increased social segregation whereby higher wages for skilled labour and increases in land prices exclude lower income groups from moving into better-off neighbourhoods. As segregation is practiced by upper income groups, the cost of acquisition of human capital rises in poorer neighbourhoods due both to the deterioration of public goods and the lack of spillover effects that usually originate from a larger pool of skilled labour. In a seminal paper, Cutler and Glaeser (1997) found that a one-standard-deviation decrease in segregation would eliminate one-third of the black-white differential in schooling and employment outcomes in the USA. Other studies have suggested that neighbourhood characteristics, such as average educational level of adults, contribute to poverty-inducing factors such as teenage pregnancy and low-level schooling achievement among the young (Durlauf 2000). Wilson (1995) famously argued that residential segregation may contribute towards labour market discriminations and, consequently, to differences in initial opportunities between those individuals that live in better areas and those that live in less desirable residential districts (see also Sethi and Somamathan 2004). Furthermore, because credit constraints tend to accentuate forms of residential segregation, credit imperfections, local segregation and discrimination can operate together and lead to a cumulative process of socially inefficient persistent inequality (Piketty 2000). Low levels of cooperation and trust between groups may, in turn, affect the effectiveness and outcomes of forms of collective action.

\subsection{Efficiency and coordination of collective organisations in the presence of inequalities}

In addition to individual participation and group cooperation and trust, inequality may also affect the efficiency of collective action organisations in achieving common goals and their ability to coordinate collective action in ways that minimise free-riding and moral hazard problems. First, high levels of inequality within collective action groups or organisations could lead to bargaining disputes over the benefits of collective action, resulting in less than efficient outcomes, because most of the energy and time of the group is spent in resolving conflicts (Bardhan 2005). Second, negotiation and enforcement costs in cooperative arrangements may increase when inequality within the group is high (Bardhan 2005; Miguel and Gugerty 2005). In particular, monitoring free-riding and moral hazard behaviours may be more difficult to achieve in heterogeneous groups (Arnott and Stiglitz 1991; Ben-David 1998).

These effects are, however, dependent on the interests of elites. Acemoglu and Robinson (2006) and North et al. (2009) have argued, respectively, that 'inclusive institutions' and 'open access societies' may emerge when they are in the interests of elites. Similar mechanisms could be at play at the level of local collective action organisations if the elites that participate in these groups have a vested interest in the outcome of collective action (Bardhan 2005; Olson 1965). In that case, it is possible that inequalities may not matter much for the efficiency of the group. However, it is also possible that elites may either engage in rent-seeking activities or disengage from the group. Banerjee et al. (2001) show that within-group inequality has resulted in lower efficiency in sugar cooperatives in Maharashtra, India, due to rent-seeking behaviour from wealthier cooperative members, who maintain low sugar prices in order to benefit (economic and socially) from rents that are generated by the cooperative. Elites may also stop using local public goods (such as schools and health care), leading to forms of neighbourhood or community segregation (Bardhan 2005).

One particularly relevant example is when elite interests in highly unequal groups lead to failures in how collective action may be used in redistribution demands. As discussed above, Piketty (1996) shows how rises in inequality may be accompanied by reductions in redistribution. These effects could, for instance, explain the prevalence of inefficient, nonprogressive or even regressive fiscal systems. In a survey of tax incidence in a sample of 20 developing and in transition countries, Chu, Davoodi and Gupta (2000) found that tax systems were progressive in just over a third of cases. About a fifth of all cases were 
regressive and the remainder neutral. Implementing progressive tax systems in developing countries is very difficult, given the existence of weak governments, influenced by elites and affected by corruption, political interests, the persistence of high tax evasion and the existence of very small taxable income bases (Newbery and Stern 1987; Radian 1980). Inequalities may exacerbate this situation due to failures in the coordination of collective action for more redistribution.

\section{Final remarks: a new research agenda?}

The sections above discuss how income inequality may affect collective action through changes in individual motivations to participate in collective organisations, in norms of group cooperation and trust, and in the efficiency and coordination of collective action. These are important effects because they may in turn weaken the role of collective action in reducing inequalities further in the future. Historically, local communities, citizens' associations and several other types of local organisations have played important roles in social demands for redistributive policies, social justice and the protection of vulnerable population groups. But, paradoxically, high levels of inequality may weaken the very forces that may curtail unjust social, economic and political differences across the world. In other words, high levels of income and wealth inequality may result in the prevalence of norms and institutions that will perpetuate inequalities further. Addressing this issue is key to debates on economic development because the relationship between rising income inequality, social cooperation and collective action is central to understanding how societies transition to inclusiveness, or remain trapped in vicious cycles of underdevelopment and sociopolitical instability.

These complex relationships remain, however, under-researched. In particular, several fundamental but so far unanswered questions emerge from the discussion above:

(i) What levels of income inequality cause the breakdown of participation, social cooperation and the efficiency of collective action organisations?

(ii) What types of inequality matter for collective action?

(iii) How do the effects of inequality vary across the internal structure and organisation of different collective action groups?

(iv) How do we identify empirically the causal mechanisms that underlie the theoretical and a priori unclear - association between income inequality and local collective action?

The discussion in this paper emphasised the potential role of income inequality in shaping collective action, but had less to say about the levels of inequality that may matter. Olson (1965) argued that some level of inequality may lead to more collective action in the provision of pure public goods because the better-off members of the group (those with a higher share of the income pie) would have a vested interest in the increased provision of the good. At the same time, a higher share of incomes and wealth ensures that elites contribute towards the setting up of the collective action group by compensating them for initial costs (which are typically borne by elites) (see also Wade 1988). Others, such as Banerjee et al. (2001), have documented the negative externalities that may result in the provision of collective goods when inequalities between members of the group are high. It is, therefore, likely that the effects of inequality on collective action depend on the levels of initial inequality. The model developed in Bardhan, Ghatak and Karaivanov (2006) illustrates some of these points in the case of the management of common property resources. Further research is needed across other different forms of collective action.

In addition to levels, different types of inequality may also matter differently to collective action. Inequality is a multidimensional phenomenon and it is therefore likely that not all dimensions of inequality shape collective action in similar ways. It is possible to envisage a 
situation in which some levels of income inequality may spur collective action because they compensate elites for the costs of initiating collective action (as in Olson 1965). In this case, elites benefit because they take a higher share of the collective good. Those at the bottom of the distribution also benefit because the collective good yields positive externalities. In other words, those at the bottom of the distribution are better off than in a situation where the collective good is not produced. But income or wealth inequality may lead to opposite effects when wealth differentials exist alongside other dimensions of inequality such as caste, class or ethnic-based discrimination, whereby elites are able to manipulate the structures of collective action in order to appropriate most of the gains at the cost of other members of the group (Banerjee et al. 2001; Gaspart and Platteau 2006). Social distances between members of collective action groups may also affect individual participation in the group and the structures of within-group cooperation (Cardenas 2006; Gaspart and Platteau 2006). To date, limited research has been conducted on how different types of inequalities may interact in shaping the functioning of collective action arrangements.

In terms of the internal structure and organisation of collective action groups, the paper has implicitly assumed that collective action groups are mostly self-governing and contributions are voluntary. But the structure of the collective action group may affect substantially the relationship between inequality and collective action in two ways: (i) whether the group is self-regulatory or whether a common authority can enforce taxation and use that to provide public goods (Baland and Platteau 2006; Bardhan et al. 2006), or (ii) whether contributions to the collective good are voluntary or regulated (Baland and Platteau 2006; Janssen and Ostrom 2006). In addition, the aim of the collective action group may also shape how income inequality may affect collective action through the mechanisms discussed in the previous section. For instance, trade unions and common-property-resources user groups may act in entirely different ways because the collective good that emerges from these different forms of collective action may yield different externalities. Trade unions result in a collective good (higher salaries) with positive externalities. In this case, it is possible that inequalities within the group matter less than in the case of common property resources, where negative externalities in the use of the resource (lower availability of local resources) may facilitate appropriation by the wealthier and more powerful (Bardhan et al. 2006; Janssen and Ostrom 2006). The question of how the effects of income inequality on collective action may vary across different types of groups is a very compelling area of future research as different forms of collective action may produce an array of development outcomes in different parts of the world.

Finally, the answers to the questions above are partly constrained by empirical limitations, particularly in terms of the availability of data that can be compared across countries. Despite recent improvements, the systematic compilation of data on inequality still faces considerable challenges (particularly beyond a handful of mostly developed countries). Data on collective action are also difficult to find beyond a small number of countries, limiting how we can currently address the questions discussed above. The analysis of the causal mechanisms that may shape the relationship between inequality and collective action presents further difficulties. However, recent developments in behavioural economics, and a closer relationship between economics, sociology and social psychology research, has offered new insights into foundations of social cooperation, trust and individual preferences for pro-social norms (see Cardenas and Carpenter 2008). In addition, new links between behavioural data and socioeconomic outcomes indicate that progress in this area of research may be possible. Data on collective organisations are also being collected more systematically in large socioeconomic surveys - such as the Living Standards Measurement Study (LSMS) and Demographic and Health Surveys (DHS) Program - showing a promising avenue for future comparative empirical work across countries. 


\section{References}

Acemoglu, D. and Robinson, J. (2012) Why Nations Fail: The Origins of Power, Prosperity and Poverty, London: Profile Books

Acemoglu, D. and Robinson, J. (2006) Economic Origins of Dictatorship and Democracy, Cambridge: Cambridge University Press

Akerlof, G.A. (1976) 'The Economics of Caste and of the Rat Race and Other Woeful Tales', Quarterly Journal of Economics 90.4: 599-617

Akerlof, G.A. and Kranton, R.E. (2000) ‘Economics and Identity', Quarterly Journal of Economics 115.3: 715-53

Alesina, A. and LaFerrara, E. (2005) 'Ethnic Diversity and Economic Performance', Journal of Economic Literature 43: 762-800

Alesina, A. and LaFerrara, E. (2002) 'Who Trusts Others?', Journal of Public Economics 85: 207-34

Alesina, A. and Rodrik, D. (1994) 'Distributive Politics and Economic Growth', Quarterly Journal of Economics 109.2: 465-90

Alesina, A.; Cozzi, G. and Mantovan, N. (2012) 'The Evolution of Ideology, Fairness and Redistribution', Economic Journal 122.565: 1244-61

Algan, Y. and Cahuc, P. (2010) 'Inherited Trust and Growth', American Economic Review 100.5: 2060-92

Arnott, R. and Stiglitz, J. (1991) 'Moral Hazard and Nonmarket Institutions: Dysfunctional Crowding Out or Peer Monitoring?', American Economic Review 8.1: 179-90

Atkinson, A. and Piketty, T. (2010) Top Incomes: A Global Perspective, Oxford: Oxford University Press

Atkinson, A. and Piketty, T. (2007) Top Incomes over the Twentieth Century: A Contrast Between Continental European and English-Speaking Countries, Oxford: Oxford University Press

Attanasio, O.; Barr, A.; Cardenas, J.C.; Genicot, G. and Meghir, C. (2012) 'Risk Pooling, Risk Preferences and Social Networks', American Economic Journal: Applied Economics 4.2: $134-67$

Axelrod, R. and Hamilton, W. (1981) 'The Evolution of Cooperation', Science 211: 1390-96

Baland, J-M. and Platteau, J-P. (2006) 'Collective Action on the Commons: The Role of Inequality', in J-M. Baland, P. Bardhan and S. Bowles (eds), Inequality, Cooperation, and Environmental Sustainability, Princeton NJ: Princeton University Press

Baland, J-M.; Bardhan, P. and Bowles, S. (eds), Inequality, Cooperation, and Environmental Sustainability, Princeton NJ: Princeton University Press

Banerjee, A.; lyer, L. and Somanathan, R. (2005) 'History, Social Divisions and Public Goods in Rural India', Journal of the European Economic Association 3: 639-47 
Banerjee, A.; Mookherjee, D.; Munshi, K. and Ray, D. (2001) 'Inequality, Control Rights, and Rent Seeking: Sugar Cooperatives in Maharashtra', Journal of Political Economy 109.1: 138-90

Bardhan, P. (2005) Scarcity, Conflicts, and Cooperation, Cambridge MA: MIT Press

Bardhan, P.; Ghatak, M. and Karaivanov, A. (2006) 'Inequality and Collective Action', in J-M. Baland, P. Bardhan and S. Bowles (eds), Inequality, Cooperation, and Environmental Sustainability, Princeton NJ: Princeton University Press

Barrett, C. (2005) (ed.) The Social Economics of Poverty: On Identities, Communities, Groups and Networks, Oxford/New York: Routledge

Becker, G.S. (1967) 'Crime and Punishment: An Economic Approach', Journal of Political Economy 76.2: 169-217

Ben-David, D. (1998) 'Convergence Clubs and Subsistence Economies', Journal of Political Economy 55: 153-59

Benabou, R. (1993) 'Workings of a City: Location, Education and Production', Quarterly Journal of Economics 108.3: 619-52

Bernard, T.; Dercon, S. and Taffesse, A.S. (2011) Beyond Fatalism: An Empirical Exploration of Self-Efficacy and Aspirations Failure in Ethiopia, Working Paper 2011-03, Oxford: Centre for the Study of African Economies, University of Oxford

Besley, T. and Persson, T. (2011) Pillars of Prosperity: The Political Economics of Development Clusters, Princeton NJ: Princeton University Press

Besley, T.; Coate, S. and Loury, G. (1993) 'The Economics of Rotating Savings and Credit Associations', American Economic Review 83: 792-810

Birdsall, N. and Londoño, J.L. (1997) 'Asset Inequality Matters: An Assessment of the World Bank's Approach to Poverty Reduction', American Economic Review 87: 32-37

Boix, C. (2003) Democracy and Redistribution, New York NY: Cambridge University Press

Bourdieu, P. (1986) Distinction: A Social Critique of the Judgment of Taste, London: Taylor \& Francis

Bowles, S. and Gintis, H. (2004) 'Persistent Parochialism: Trust and Exclusion in Ethnic Networks', Journal of Economic Behavior \& Organization 55: 1-23

Bowles, S. and Gintis, H. (2011) A Cooperative Species: Human Reciprocity and Its Evolution, Princeton NJ: Princeton University Press

Bowles, S.; Durlauf, S. and Hoff, K. (2006) Poverty Traps, Princeton NJ: Princeton University Press

Bowles, S.; Loury, G and Sethi, R. (2014) 'Group Inequality', Journal of the European Economic Association 12.1: 129-52

Cardenas, J.C. (2006) 'Wealth Inequality and Overexploitation of the Commons: Field Experiments in Colombia', in J-M. Baland, P. Bardhan and S. Bowles (eds), Inequality, Cooperation, and Environmental Sustainability, Princeton NJ: Princeton University Press 
Cardenas, J.C. and Carpenter, J. (2008) 'Behavioural Development Economics: Lessons from Field Labs in the Developing World', Journal of Development Studies 44: 311-388

Chu, K.; Davoodi, H. and Gupta, S. (2000) Income Distribution and Tax, and Government Spending in Developing Countries, WIDER Working Paper 214, Helsinki: UNU/WIDER

Coleman, J. (1990) Foundations of Social Theory, Cambridge MA: Belknap

Cox, J. (2004) 'How to Identify Trust and Reciprocity', Games and Economic Behavior 46: 260-81

Cutler, D. and Glaeser, E. (1997) 'Are Ghettos Good or Bad?', Quarterly Journal of Economics 112.3: 827-72

Datt, G. and Ravallion, M. (1992) 'Growth and Redistribution Components of Changes in Poverty Measures: A Decomposition with Applications to Brazil and India in the 1980s', Journal of Development Economics 38.2: 275-95

Durlauf, S. (2006) 'Groups, Social Influences and Inequality', in S. Bowles, S.N. Durlauf and K. Hoff (eds), Poverty Traps, Princeton NJ: Princeton University Press

Durlauf, S.N. (2000) 'The Membership Theory of Poverty: The Role of Group Affiliations in Determining Socio-economic Outcomes', Dept. of Economics, mimeo, University of Wisconsin

Durlauf, S. (1996) 'A Theory of Persistent Income Inequality', Journal of Economic Growth 1: 75-93

Easterly, W. and Levine, R. (1997) 'Africa's Growth Tragedy: Policies and Ethnic Divisions', Quarterly Journal of Economics 112: 1202-50

Easterly, W.; Ritzen, J. and Woolcock, M. (2006) 'Social Cohesion, Institutions, and Growth', Economics and Politics 18.20: 103-120

Eckel, C. and Grossman, P.J. (2001) 'The Relative Price of Fairness: Gender Differences in a Punishment Game', Journal of Economic Behavior and Organization 30.2: 143-58

Engerman, S. and Sokoloff, K. (2002) Factor Endowments, Inequality and Paths of Development Among New World Economics, NBER Working Paper 9259, Cambridge MA: National Bureau of Economic Research

Esteban, J. and Ray, D. (1994) 'On the Measurement of Polarization', Econometrica 62: 819-52

Esteban, J. and Schneider, G. (2008) 'Polarization and Conflict: Theoretical and Empirical Issues', Journal of Peace Research 45.2: 131-41

Fafchamps, M. (1992) 'Solidarity Networks in Pre-Industrial Societies: Rational Peasants in a Moral Economy', Economic Development and Cultural Change 41.2: 147-73

Fafchamps, M. and Lund, S. (2002) 'Risk-Sharing Networks in Rural Philippines', Journal of Development Economics 71: 261-87

Fajnzylber, P.; Lederman, D. and Loayza, N., 1998. Determinants of Crime Rates in Latin America and the World: An Empirical Assessment, Washington DC: World Bank

Freeman, R.B. and Medoff, J.L. (1984) What Do Unions Do?, New York: Basic Books 
Galor, O. and Zeira, J. (1993) 'Income Distribution and Macroeconomics', Review of Economic Studies 60.1: 35-52

Gambetta, D. (1988) Trust: Making and Breaking Cooperative Relations, New York: Blackwell

Gaspart, F. and Platteau, J-P. (2006) 'Heterogeneity and Collective Action for Effort Regulation: Lessons from Senegalese Small-Scale Fisheries', in J-M. Baland, P. Bardhan and S. Bowles (eds), Inequality, Cooperation, and Environmental Sustainability, Princeton NJ: Princeton University Press

Genicot, G. and Ray, D. (2014) Aspirations and Inequality, NBER Working Paper 19976, Cambridge MA: National Bureau of Economic Development

Glaeser, E.; Laibson, D.; Scheinkman, J. and Soutter, C. (2000) 'Measuring Trust', Quarterly Journal of Economics 115.3: 811-46

Gottschalk, R. (2003) 'Inequality and the Macro-Economy in Latin America', Consultancy Report prepared for the Department for International Development (internal document)

Gupta, K.D. (1990) The Economics of Political Violence: The Effect of Political Instability on Economic Growth, New York: Praeger

Gurr, T.R. (1970) Why Men Rebel, Princeton NJ: Princeton University Press

Habyarimana, J.; Humphreys, M.; Posner, D. and Weinstein, J. (2009) Coethnicity: Diversity and the Dilemmas of Collective Action, New York: Russell Sage Foundation

Hirschman, A. (1981) Essays in Trespassing: Economics to Politics and Beyond, Cambridge: Cambridge University Press

Hoffman, E.; McCabe, K. and Smith, V. (1996) 'Social Distance and Other Regarding Behavior in Anonymous Dictator Games', American Economic Review 86.3: 653-60

Janssen, M. and Ostrom, E. (2006) 'Adoption of a New Regulation for the Governance of Common-Pool Resources by a Heterogeneous Population', in J-M. Baland, P. Bardhan and S. Bowles (eds), Inequality, Cooperation, and Environmental Sustainability, Princeton NJ: Princeton University Press

Jappelli, T. and Pistaferri, L. (2000) 'Using Subjective Income Expectations to Test for Excess Sensitivity of Consumption to Predicted Income Growth', European Economic Review 44: 337-58

Justino, P. (2015) Civil Unrest and Government Transfers in India, IDS Evidence Report 108, Brighton: IDS

Justino, P. (2013) 'Shared Societies and Armed Conflict: Costs, Inequality and the Benefits of Peace', in Clem McCartney and Wim Naudé (eds), Shared Societies and Global Development, Oxford: Club de Madrid

Justino, P. (2007) Carrot or Stick? Redistributive Transfers versus Policing in Contexts of Civil Unrest, MICROCON Research Working Paper 3, MICROCON - A Micro-Level Analysis of Conflict, EU Integrated Project, Brighton: MICROCON, University of Sussex, www.microconflict.eu (accessed 28 May 2015)

Justino, P. (2006) 'The Impact of Collective Action on Economic Development: Empirical Evidence from Kerala, India', World Development 34.7: 1254-70 
Karlan, D.; Möbius, M.; Rosenblat, T. and Szeidl, A. (2009) 'Trust and Social Collateral', Quarterly Journal of Economics 124.3: 1307-61

Knack, S. and Keefer, P. (1997) 'Does Social Capital Have an Economic Payoff? A CrossCountry Investigation', Quarterly Journal of Economics 112.4: 1251-88

Kranton, R. (1996) 'Reciprocal Exchange: A Self-Sustaining System', American Economic Review 86.4: 830

Kremer, M. (1993) 'The O-Ring Theory of Economic Development', Quarterly Journal of Economics 108: $551-75$

Langer, A. (2004) Horizontal Inequalities and Violent Conflict: The Case of Cote D'Ivoire, CRISE Working Paper 13, Oxford: Centre for Research on Inequality, Human Security and Ethnicity, University of Oxford

Lichbach, M.I. (1989) 'An Evaluation of "Does Economic Inequality Breed Political Conflict?" Studies', World Politics 41: 431-70

Lijphart, A. (1999) Patterns of Democracy: Government Forms and Performance in Thirty-Six Countries, New Haven CT: Yale University Press

Lijphart, A. (1997) ‘Unequal Participation: Democracy’s Unresolved Dilemma’, American Political Science Review 91.1: 1-14

Manski, C. (2004) 'Measuring Expectations', Econometrica 72.5: 1329-76

McCulloch, N.; Winters, A. and Cirera, X. (2001) Trade Liberalisation and Poverty: A Handbook, London: Centre for Economic Policy Reseach

Meltzer, A. and Richard, S. (1981) 'A Rational Theory of the Size of Government', Journal of Political Economy 89.5: 914-27

Miguel, E. and Gugerty, M. (2005) 'Ethnic Diversity, Social Sanctions and Public Goods in Kenya', Journal of Public Economics 89.11-12: 2325-68

Milanovic, B. (2011) The Haves and Have-Nots: A Brief and Idiosyncratic History of Global Inequality, New York: Basic Books

Milanovic, B. (2002) 'True World Income Distribution, 1988 and 1993: First Calculations Based on Household Surveys Alone', Economic Journal 112: 51-92

Montalvo, J. and Reynal-Querol, M. (2008) 'Discrete Polarization with an Application to the Determinants of Genocides', Economic Journal 118: 1835-65

Muller, E. and Seligson, M.A. (1987) 'Inequality and Insurgency', American Political Science Review 81.2: 425-51

Murphy, K.M.; Shleifer, A. and Vishny, R. (1989) 'Income Distribution, Market Size, and Industrialization', Quarterly Journal of Economics 104.3: 537-64

Murshed, M. and Gates, S. (2005) 'Spatial-Horizontal Inequality and the Maoist Insurgency in Nepal', Review of Development Economics 9: 121-34

Newbery, D. and Stern, N. (1987) The Theory of Taxation for Developing Countries, Oxford: Oxford University Press 
North, D. (1990) Institutions, Institutional Change, and Economic Performance, New York: Cambridge University Press

North, D.; Wallis, J. and Weingast, B. (2009) Violence and Social Orders: A Conceptual Framework for Interpreting Recorded Human History, New York: Cambridge University Press

Nunn, N. and Wantchekon, L. (2011) 'The Slave Trade and the Origins of Mistrust in Africa', American Economic Review 101.7: 3221-52

Olson, M. (1965) The Logic of Collective Action, Cambridge MA: Harvard University Press

Østby, G. (2006) Horizontal Inequalities, Political Environment and Civil Conflict: Evidence from 55 Developing Countries, CRISE Working Paper 28, Oxford: Centre for Research on Inequality, Human Security and Ethnicity, University of Oxford

Ostrom, E. (1990) Governing the Commons: The Evolution of Institutions for Collective Action, Cambridge: Cambridge University Press

Oxfam (2014) Even It Up: Time to End Extreme Inequality, Oxford: Oxfam

Paige, J. (1975) Agrarian Revolutions, New York: Free Press

Perotti, R. (1993) 'Political Equilibrium, Income Distribution and Growth', Review of Economic Studies 60.4: 755-76

Piketty, T. (2013) Capital in the Twenty First Century, Cambridge MA: Belknap/Harvard

Piketty, T. (2000) 'Theories of Persistent Inequality and Intergenerational Mobility', Chapter 8 in A. Atkinson and F. Bourguignon (eds), Handbook of Income Distribution, Vol. 1, Amsterdam: North-Holland

Piketty, T. (1996) 'The Politics of Redistribution: Recent Developments and Research Perspectives', paper prepared for the 1996 meeting of the McArthur Foundation Costs of Inequality Project, Boston 3-5 May 1996

Platteau, J-P. (2004) 'Monitoring Elite Capture in Community-Driven Development', Development and Change 35

Putnam, R. (1993) Making Democracy Work, Princeton NJ: Princeton University Press

Radian, A. (1980) Resource Mobilization in Poor Countries, London: Transaction Books

Ravallion, M. (2013) 'More Relatively-Poor People in a Less Absolutely-Poor World', Review of Income and Wealth 59.1: 1-28

Ravallion, M. (2005) 'A Poverty-Inequality Trade-off?', Journal of Economic Inequality 3.2: 169-81

Ravallion, M. (1997) Can High-Inequality Developing Countries Escape Absolute Poverty?, Washington DC: World Bank

Rawls, J. (1971) A Theory of Justice, Cambridge MA: Harvard University Press

Ray, D. (2006) 'Aspirations, Poverty, and Economic Change', in A. Banerjee, R. Benabou and D. Mookherjee (ed.), Understanding Poverty, Oxford: Oxford University Press 
Ribero, R. and Nuñez, J. (1999) Productivity of Household Investment in Health: The Case of Colombia, Working Paper R-354, Washington DC: Inter-American Development Bank

Rosenzweig, M. (1988) 'Risk, Implicit Contracts and the Family in Rural Areas of Low-Income Countries', Economic Journal 98.393: 1148-70

Saint-Paul, G. and Verdier, T. (1992) Education, Democracy and Growth, Discussion Paper 613, London: Centre for Economic Performance Research

Sala-i-Martin, X. (1996) Transfers, Social Safety Nets and Economic Growth, IMF Working Paper WP/96/40, Washington DC: International Monetary Fund

Schelling, T.C. (1966) The Strategy of Conflict, New York: Oxford University Press

Schock, K. (1996) 'A Conjectural Model of Political Conflict: The Impact of Political Opportunities on the Relationship Between Economic Inequality and Violent Political Conflict', Journal of Conflict Resolution 40.1: 98-133

Scott, J. (1976) The Moral Economy of the Peasant: Rebellion and Subsistence in Southeast Asia, New Haven CT: Yale University Press

Sen, A. (1973) On Economic Inequality, Oxford: Oxford University Press

Sethi, R. and Somanathan, R. (2004) 'Inequality and Segregation', Journal of Political Economy 112.6: 1296-1321

Stewart, F. (2002) Horizontal Inequalities: A Neglected Dimension of Development, QEH Working Paper Series 81, Oxford: University of Oxford

Stewart, F. (2000) 'Crisis Prevention: Tackling Horizontal Inequalities', Oxford Development Studies 28.3: 245-62

Thöni, C.; Tyran, J-R. and Wengström, E. (2012) 'Microfoundations of Social Capital', Journal of Public Economics 96: 635-43

Tilly, C. (1998) Durable Inequality, Berkeley CA: University of California Press

Townsend, R. (1994) 'Risk and Insurance in Village India', Econometrica 62.3: 539-91

Varshney, A. (2002) Ethnic Conflict and Civic Life: Hindus and Muslims in India, New Haven CT: Yale University Press

Wade, R. (1988) Village Republics: Economic Conditions for Collective Action in South India, Cambridge: Cambridge University Press

Wilson, W. J. (1995) The Truly Disadvantaged, Chicago: University of Chicago Press

Winters, L. A. (2002) 'Trade, Trade Policy and Poverty: What Are the Links?', World Economy 25, 1339-67

Wood, A. (1994) North-South Trade, Employment and Inequality: Changing Fortunes in a Skill-Driven World, Oxford: Clarendon Press

Woolcock, M (1998) 'Social Capital and Economic Development: Toward a Theoretical Synthesis and Policy Framework', Theory and Society 27.2: 151-208

World Bank (2011) World Development Report 2011, Washington DC: World Bank 
World Bank (2004) Community-Driven Development in Local Government Capacity Building Projects: Emerging Approaches in Africa, Social Development Notes 86 (November), Washington DC: World Bank

World Bank (2003a) World Development Report 2003, Washington DC: World Bank

World Bank (2003b) Inequality in Latin America and the Caribbean: Breaking With History?, Washington DC: World Bank

World Bank (2000) The Community Driven Development Approach in the Africa Region: A Vision of Poverty Reduction Through Empowerment, Washington DC: World Bank 